\title{
La ville en vol/City in Flight: Tracing Lesbian E-Motion Through Montréal
}

\author{
Barbara Godard
}

\section{La ville en vol: topologie du mouvement lesbien à Montréal}

La mobilité est le trope du corps urbain. Le développement de la ville, l'émergence du roman réaliste, la domination d'une économie scopique sont figurés par le flâneur de la fin du dix-neuvième siècle. Dans les années trente, la modernité se figure cornme une femme se promenant en auto. C'est une femme légère, comme la putain, l'objet du regard du flâneur car c'est une économie sexuée. Pour déplacer une telle économie de solides par une économie de fluides, une économie autre où une femme est à la fois le sujet et l'objet du désir, la flâneuse de Marchessault promène son regard de sujet-femmeà travers la ville. Cependant, la rapiditéde son mouvement dans les espaces cosmiques, la topographie de Montréal et le rythme vertigineux de ses mots qui "lévitent" avec/dans la bibliothèque municipale comme une machine à traverser le temps, figurent l'esprit mercurien de Montréal, font vibrer les axes de sa syntaxe urbaine. Dans la grammaire géographique, ceux qui veulent la permanence s'accrochent à la montagne tandis que ceux qui recherchent le changement se pointent vers le fleuve. Marchessault transforme ce réseau de signes topographiques pour aligner le fleuve et la montagne dont la croix "unit les quatre vents, les quatre forces de l'Oiseau-Tonnerre" qui font vibrer cette ville mortuaire pour la libérer du cannibalisme européen. Ce mythe du contrat sacrificiel se transforme dans la figuration d'un ordre symbolique entre femmes autour de la grand-mère, la Mère des herbes, une transformation dans l'ordre du discours réglant le corps politique.

The city, "la ville," configured in terms of modernist topoï of isolation, threshold, ontological break and nothingness, is exposed as object for the male gaze limiting women's action in Jovette Marchessault's trilogy, Comme un enfant de la terre.

Refiguring masculinist mythemes, Marchessault transmutes the flâneuse or street walker of ill repute, synecdoche of the excessive commercialism of the city, guardian of the void, into a voleuse, an amazon. 
angel who soars in the realm of the "night cow" (Marchessault 1980), covering the crepuscular city with "énergie stellaire" (Marchessault $1975,210)$ in a promise of plenitude, so bringing into being a different economy of desire within the body politic. E-motion as transformation. ${ }^{1}$

The ground level point of view of the flâneur is confounded with the visionary scope of the flyer's panoramic view to the point of contradiction. The city as "les abstractions aériennes, ce qui peut se construire en hauteur" coexists with its geometrization "pour accéder à une vision objective de sa réalité" (Marchessault 1975, 200, 201): "car ce qui se dresse souverainement, impérieusement vers le ciel sur sa tige doit aussi se maintenir en contact avec la terre" (Marchessault 1975, 199). Here Babylon is Jerusalem the Golden as the title of the first volume, Le crachat solaire, announces. The vomit ("crachat") of the topos of urban misery and rejection is simultaneously solar spit (rays), sign of cosmic transcendence. Marchessault plays thus on the double semiotic axes of the city novel, exploring the constraints and tensions of the bitterness of daily life in specific closely-observed neighbourhoods (the detail of the worn linoleum floor in the lodging on "rue Workman," Marchessault 1975, 238) from the whirlwind energy generated by a global perspective, contemplating the city as site of loss and death (tragedy) yet paradigm of reterritorialization, simultaneously site of sacrifice and transcendence. Personal memory - her first art exhibit at Maison des Arts de la Sauvegarde (Marchessault 1975, 181) - is conjugated with and against "national" history - the founding of Montréal in the month of Mary, May $17 / 18,1642$ (Marchessault 1975, 180) - in a double exposition of the past telescoped through the present. The tragedy of the everyday is traversed by myths of origin in a double movement (dialectic) between near/far as paradigms of order (Lefebvre). This produces "un univers de plénitude" in the "dynamisme des contraires" (Marchessault 1975, 206).

"Through" is the operative word in my title. Montréal is, as Marchessault writes, "une ville médiumnique" (Marchessault 1975, 202). Metaphors of voyage and threshold are prominent in her work, as she acknowledges (Potvin 228). For her doubled narration works not to compound the effect of dissociation and fragmentation in images of the city but to read one image through another in a fluid interconnection, an enfolding of one within the other by means of apostrophe, litany, parataxis (Godard 1991) that plays out to excess the trope of the city as place of passage, exchange and transformation. Le crachat solaire marks the arrival of women in the city and their working through (and over) its 
signs. This is Jovette Marchessault's "aerial letter," her fiction in the future perfect that posits a/n[other], virtual(?) "reality."

Cette ville est mercurienne le matin avec ce que cela implique de jeunesse, d'envol, de présent immédiat... Elle est mercurienne avec ce que cela implique de facilité d'adaptation, de mobilité d'esprit. Elle se déplace dans l'air avec toutes ses formes, ses mutations nerveuses, rapides, ses familles, ses cousins, ses sacs de sable pour les petits voyages sur les routes gelées, glissantes. Elle correspond avec chacun de nous, nous éduque, nous examine, nous tâte le pouls, vagabonde en surabondance d'église, d'électricité, toujours souple, toujours assez jeune pour goûter l'ivresse de l'air d'en haut au centre vivant de ses origines, au-delà de son commencement (Marchessault 1975, 195-6).

In this vertiginous flux is born Montréal which Jovette Marchessault calls "my city," "universelle comme le ventre de la baleine, cosmopolite comme la tour de Babel, voix presque consolante en terre amérindienne" (Marchessault 1975,190). “À Montréal, je me sens parfaitement chez moi et je rime à quelque chose" (Marchessault 1975, 195). With these phrases begins a paean to the city of Montréal by a narrator of celestial origins, born of the Great Bear as solar spittle, coming to earth in this MontréalVille-Marie-Hochelaga on Native sacred territory. Evident here is Marchessault's narrative strategy of enfolding and telescoping. There is no separation between the " $\mathrm{je}$ " and the "nous"; personal and national fuse in the urban corps, rewriting and so displacing, the myth of urban anomie. The dispersion of the fall into Babel and the proliferation of incomprehensible languages is paradoxically reterritorialization on Native soil in a different language and culture with different orderings of space, time and gender. This dispersion which is also a return is figured in the telescoped history of Montréal as a figure of regress through its Christian founding as Ville-Marie, in dedication to the Virgin, back to an earlier founding as the generally forgotten, mysterious Native city of Hochelaga. In Marchessault's toponymy, the three names are hypenated as a composite entity, the trace of the past activating the present. A cryptic formulation of the many and divergent origin myths of the body politic, this is also a recontextualization within a pagan, goddess-centred order. A parallax, this shift in angle of vision produces difference within the urban corps. 
This aerial vision of Montréal, the city Marchessault flies over and makes fly, is vanishing point, at once ground and limit in the present tense of writing, in the fulgurant rhythms of her sentences, writing which is "la machine à traverser le temps" (Marchessault 1975, 89). "Le temps a passé avec le vertige à la lisière des bois," she writes, beginning a paragraph that meditates on the Mount Royal cross open to the four winds, a paragraph that functions as transition between a section describing the founding of Montréal as recorded by its two "visionary" fathers, Jérôme [le Royer de la Dauversière] and Jacques [Olier] (Marchessault 1975, 191), and the narrator's descent from the Greyhound bus at the Dorchester terminus which marks her arrival in the city (Marchessault 1975, 194). A repetition of foundation narratives with a difference, of gender and race. The city is refounded symbolically in this return to origins ever displaced towards the ab-original. Before she sets out on her flânerie along Ste-Catherine, there is yet another abrupt shift in perspective to describe the origins of Hochelaga in the work of clearing and planting of five Iroquois tribes. This narrative process involves superimposing past and future, oscillating between memory and hallucinatory vision, to imag(in)e a wor(l)d city, in this palimpsest producing a coming-to- woman (advenir femme). For writing and reading produce effects of the real having real effects on bodies, biological and political. Fiction is a mode of intervening to realign the real.

Reading and writing are the principal modes of locomotion in the city. As Marchessault writes: "[J]e n'étais qu'un lieu de passage pour ces livres qui circulent dans l'éther comme des comètes" (Marchessault $1975,58)$. The public library is the nodal point of urban networks, the narrator's preferred place. It is a magic site, where she reads, "levitates," and inititates metamorphoses, re-citing knowledge of the past (Marchessault 1980, 178-9). Three connected networks may be discerned here-text, body, and city - through which the narrator traces a trajectory of desire. Certain arteries or trajectories are blocked in the city as "paved solitude" (Pike 24) that tries to "snuff out" the creatures born of the dreams of those who have and who will inhabit the place, this city which is nonetheless "née d'une vision" (Marchessault 1975, 197, 196). The trope of "circulation," figured here in the moving ray of heavenly light and the leaping greyhound, proper to extra-urban movement (through cosmic space and the American continent respectively), and the walking woman moving through the city, posits the conditions for movement in signification produced by an economy in excess of the dominant econ- 
omy of desire, that is an economy in which a woman is simultaneously both subject and object of desire, no longer constrained to be the object of the masculine gaze.

This rereading/rewriting transports the female subject to a different space, to a world parallel to and critical of contemporary sociality. A utopian world $?^{2}$ However, this is also a lost or forgotten world that is (re)constituted in/as narration when "je me souviens avec une précision hallucinatoire," participating thus in the "immense force créatrice de la mémoire" (Marchessault 1988,71). Marchessault's texts effect "la traversée des apparences" (Potvin 225) or a "traversée des signes" in a process where the narrator is initiated to the memory of time and the secrets of creation. Particularly her texts affirm ancient and forgotten knowledges of Native peoples that respect the energies of all living things and the power of the feminine. Central to this is the fable of the hens which takes up much of the Ninth "Canto" and introduces the important figure of the grandmother as culture hero, initiating the young narrator to drawing and music that transform the world.

J'avais neuf ans. Je franchissais une ligne de démarcation. J'apprenais que rien n'est plat, banal; qu'un rapport intense, fait d'affection, d'émotion, de passion peut nous relier à tout ce qui nous entoure... Dans cette cuisine glaciale sordide, j'arrivais presque à saisir le sens de ma naissance. Il me semblait que mon père et ma mère m'avaient à peine choisie, que c'était peut-être moi qui au contraire les avait choisis. (Marchessault 1975, 253)

This lesson of the power of imagination and love transcends the white snow (synecdoche of the void) descending on the urban squalor of the working class district in which she is living, "un quartier sinistre" with dark, deserted streets and a house that is a veritable "cercueil" (Marchessault 1975,240,241). In the very midst of this topos of the city as negativity, "crépuscule, enterrés" (Marchessault 1975, 239), there emerges creation, joy and transcendence. This comes through the power of the pen. The narrator remembers herself as child struggling to draw animals at the kitchen table. Her grandmother, encouraging her, can no longer resist the attraction of pen and paint and starts to draw hens with an elan of heart and spirit, eccentric hens of every imaginable sort, "des poules du commencement du monde, de fin du monde face à un paysage de casseroles" (Marchessault 1975, 250). Her enthusiasm communicates itself to the child who, with renewed confidence, takes up her pencil to 
draw birds. So commences her life as an artist. "J'entrais dans le monde, dans les pores du papier" (Marchessault 1975, 252). Grandmother culminates this eventful evening by playing the piano, "la musique telle qu'elle la pratiquait était d'origine céleste" so that as she plays, all the signs of urban negativity, especially metaphors of sickness, are banished: "elle libérait des vapeurs, des gaz toxiques, des bactéries, des pneumocoques" (Marchessault 1975,255). Artistic creation will disrupt the existing order initiating an ontological break that brings animation and mobility in the place of stagnation and stasis.

In the cosmology of Marchessault, the process of creation is carried out through sound, through speech, through the word. The sentence of Creation is long, interminable, ever recommencing: Marchessault blends her narrative voice with the cosmic song to produce her text in "Cantos" rather than "chapters," in invocations, litanies of the names of the country rather than in exposition or description of places (Godard 1991). If in Le crachat solaire Marchessault tells the voyage of the narrator prior to her birth, and aligns Montréal with the elemental forces, with cosmic space-time, in La mère des herbes, she repeats this autobiographical narrative of the narrating subject to situate it within a female genealogy, a knowledge specific to women transmitted orally from grandmother to granddaughter, a knowledge figured here by Grandmother Louisa, Plant goddess, "la mère des herbes" (Marchessault 1980, 235). In Des cailloux blancs pour les forêts obscures the action removes to the cosmic dimensions to recount a tale of aviators and the angelic figure of the Lion of Bangor. Significantly, only here does Marchessault develop amorous relations between women as explicitly sexual. Paradoxically, Marchessault's trilogy shows that the only way to fully inhabit the city is to leave it, to move through it on the way to somewhere else. This is necessary, she suggests, because the modern city has obliterated its Native origin as Hochelaga and along with it all the vitalizing herbal lore and the political savvy of the "Grandmothers" or wise women of the tribe who cared for its body politic.

In this trilogy, Marchessault celebrates the coming out from the woods of a hybridized culture whose origins are to be found by digging in the soil. For Native cultures are already (t)here, underground so invisible to the dominant culture: "La terre amérindienne nous a assimilés et nous sommes blancs et nous sommes rouges" (Marchessault 1975, 184). ${ }^{3}$ Through the grandmother, the narrator asserts her own métis heritage, the trope of métissage combining with that of metamorphosis to form 
Marchessault's vision of the imaginary city as site of flux, tangled complexity, and transformation. On a formal level, this translates into the unexpected juxtaposition of family narratives and extracts from written histories of the founding of Montréal, telescoped and recontextualized as "paroles prophétiques...cueillies quelque part dans le seizième siècle, entre des récits forestiers, de voyageurs" (Marchessault $1975,146)$ to form an indictment of colonialism by first French, then English settlers: "notre histoire, les massacres, les répressions, le déclin de la race et sa descente circulaire, sanglante dans ce charnier que recouvre à peine quelques arpents de neige" (Marchessault 1975, 146). The quotation from Voltaire's celebrated dismissal of Quebec underlines Marchessault's poetics of citation, a form of collage or rewriting, that recirculates, recontextualizes, the self-evident "truths" about the "essence" of Quebec culture to call them into question, to make them speak against themselves of the repression of Native cultures.

Part of this archeological digging and reclaiming forgotten history is Marchessault's toponymy, her definitions of the crucial names "Kébec" and "Kanada" in Montagnais words for welcome (Marchessault 1975, 152,153 ), which signify an openness to the other that the present culture has suppressed in its development of repressive regimes through measures such as General Police Acts for order and good government and landholding rights, the suppression of public meetings, in this case the monopoly of the "Grandes Compagnies" (Marchessault 1975, 208, $182,209)$, which have produced a general paralysis of body and voice, silence, the great malady of colonialism (Marchessault 1975, 158) in Marchessault's troping. John-marchait-terre (also called John-marchaitair), the narrator's grandfather, a Native from the U.S. and member of a circus, testifies to the oppression of Natives on the prairie, the wiping out of buffalo herds that preceded the decimation of Native peoples and their spirit world so that "les choses volantes de l'air ne se manifestent plus" (Marchessault 1975, 269). To revivify Quebec society, this suppressed history must come out from the woods and invade the public spaces with its energetic music and dancing, with a carnival spirit that has retained the sense of "potlach" welcome and openness, the economy of expenditure and excess of ancient Hochelaga, as Marchessault imag(in)es it. This reanimating of the voices of America that preceded the French régime and extend beyond the borders of Quebec is carried out through books, through reading and quoting against the grain. The narrator locates within the pages of books "embryon d'or," "gerbe 
d'étincelles" (Marchessault 1975, 126), fragments that stimulate the imagination, point towards different ways of thinking and acting that enable her to carry out her project of changing the world, outside the frames of "Politics" with its inevitable violence, specifically of recuperating a culture that values the feminine.

One example illustrates the oblique way in which Marchessault's poetics of citation and hybridity operates. This is her allusive use of the mytheme of parturition, the act which serves as narrative frame for Le crachat solaire bringing the narrator to earth, cast out of the heavens to transform the world as a female messiah, as a daughter of the Great Bear. Marchessault does not untangle the complex history of this archetype through legends of Saint Ursula and the 11,000 virgins or through ancient myths of Artemesia as She-Bear which would confound Christian and pagan versions of female power in a contradiction focused in virgin birth. Nor does she cite the many Native stories of metamorphosis in which Bear-woman figures. Marchessault's text enacts this palimpsest in its narrative that circles impossibly around the process of gestation by which a sky child chooses an earthly family to be born into, ${ }^{4}$ her entire history with them prophetically foreseen before her birth. What Marchessault's narrative develops in this recombining of fragments is a crucial metaphor in the narrative of the founding of Montréal written by the priest Jacques Olier, one of the founding "fathers" of Montréal to whom Marchessault alludes.

The metaphor of birth has a long history in the epics of urban projects, most notably in its parallel to the Roman she-wolf, mother of Romulus and Remus. Montréal has her she-bear, an animal common in Quebec, in Olier's version of the founding of Ville-Marie, Les véritables motifs de Messieurs et Dames de la Société de Notre-Dame de Montréal pour la conversion des Sauvages de la Nouvelle-France (written ostensibly in 1643 for purposes of raising funds from the supporters of the Sociéte de NotreDame).

La première fois qu'il plut à Dieu me donner la pensée de considérer à fond le sujet de Montréal, il se présentera à mon esprit comme le partus d'une ourse délivrée de ses petits. Au commencement, ils ne paraissent qu'une masse de chair, informe, confuse et qui fait peur à voir de près; mais sitôt que la mère les a léchés et polis, on est tout étonné de voir peu à peu ces petits animaux parfaits de leur membres et capables de réjouir leur mère. Ainsi en est-il du partus de Montréal. (Olier 45, quoted in Michaud 92) 
Here a bear is the mother of the city, her offspring subsequently abandoned to uncertainty, a fate Olier wishes to prevent for the first Montrealers. The classical allusion is perhaps more active in Olier's metaphor, but it anticipates also the force of such origin myths of a founding mother and totemic animal in Native cultures, the explicit frame in which Marchessault rewrites the metaphor. ${ }^{5}$ In Olier's narrative, the instantiating parturition of "notre Ourse céleste" produces a compulsion to repeat in a series of tales of decline and fall. As Marchessault rewrites the various narratives of Celestial Bear Mothers, in the narrative of the artist-in-the-making-as-a-ray-of-sunlight, the emphasis is on the ever upward movement of the creative power of the imagination giving birth to metaphors, narratives, through which the limitations of the terrestrial may be overcome, again and again. This metaphor both acknowledges the history of Montréal as the record of the creative work of Native peoples and strong women and prophesies the extension of this work into the future. Unlike Anne Hébert and Nicole Brossard who have returned to the texts and words of these pioneer saints and heroines in their recontextualization and questioning of the official history of the cities of Québec and Montréal, Marchessault has recycled a metaphor, reworked a my theme. ${ }^{6}$ She does so to the same end, however, to expose the metaphorization of the urban corps as a gendered discourse, and to denounce the legendary feminization of the city (underlined in the extensive eulogies to the city addressed as "Elle") as illusory, a façade that in (f)act excludes women. Though the city is gendered feminine, la ville, it is not a site for women's political action.

This is the lesson the narrator learns when she sets out to walk through the city streets to take her place in its carnival. What she comes to understand is that street-life at the heart of the body politic is an affair of masquerade and travesty where the feminine figures only as fake and as object of desire. As flâneuse with her vagabond gaze of a woman subject wandering through the city streets, entering the symbolic marketplace, she finds only "tapettes" in the city centre, only men playing out the possibilities of the imagination for hybridization and masquerade in relations between men. Only men are entitled to expose and deontologize the work of gender. The exchange of glances between desiring women cannot take place in the public sphere. There is no "lesbianisme au grand jour... Apparaît à tout et chacun comme inconcevable": it's a "crime politique et [un] péché mortel" (Marchessault 1980, 203). 
The narrator walks along "La Catherine toute rutilante, toute pâmée, toute diamants et rubis, diadèmes et hochets, aisselles et pubis" with those who are "en maître du maquillage" (Marchessault 1975, 194, 196). On rue Saint-Laurent, she plunges into the carnival of an "abondance de temps et de lieux" (Marchessault 1975,206) within an economy of excess. She passes through the city like the "colporteurs" following "la Catherine" to the port toward the "saturnales" on Rue des Voltigeurs at the Tavern of Jos Beef (who died in 1889), returning in this movement through space backward in time to the nineteenth century to repeat, and re(s)cite the tales of the nightly torture of the menagerie of animals that constitutes the underside of city life, the dark primitivism of its unconscious. Jos Beef is hailed with Sigmund Freud as the expert in this aspect of the Montréal imaginary, with Hitler as the epitome of repressive evil for exterminating animal life (Marchessault 1975, 228, 229). Here Marchessault continues to blend the legends of oral tradition with the written history of the early days of Ville-Marie/Montréal, recirculating them in new combinations that are neither fiction nor legend but a different kind of hybrid, "un festin, un banquet inépuisable... qui outrepasse... le désir de combler un vide" (Marchessault 1975, 337). Marchessault situates this new literary mode under the heading of the carnivalesque, foregrounding thus her effort at political subversion of the dominant narratives regulating Montréal sociality. The activity of remembering is also framed in terms of "performance" animated by "le recoulement du grand désir" (Marchessault 1975, 327).

To transform desire, to establish new circuits of relations, is Marchessault's aim in this trilogy. According to the conventional toponymical syntax of Montréal, those who desire stability cling to the mountain, taking refuge under its cross, while those who seek change head towards the river, where the waters from north and west of the continent converge and flow to the sea (Thompson 1967). Marchessault transforms this network of signs to align the river and the mountain whose cross "unit les quatre vents, les quatre forces de l'OiseauTonnerre" (Marchessault 1975, 194), extending their vibrations to eternity, towards the cosmic forces against the limitations of terrestrial life in. the cramped city. Marchessault attributes the life in death of a "taupe souvent démentielle" of the city (Marchessault 1975,96) to the subjection of the continent to colonialism, which she calls "cannibalisme européen" (Marchessault 1975, 155); she seeks to liberate the city from this subjection by reappropriating "la terre amérindienne dans un frénésie des 
traces" (Marchessault 1975,60). To this end, she sets out to align the city with its natural environment, its American geography and Native traditions. Montréal space and time are intermingled with other American places and times through the travels of the narrator across the continent, to Mexico with Malcolm Lowry, to California with Jack Kerouac, towards the Rockies with the explorers and Voyageur, to Latin America to learn the treasures of the Mayans recorded in the Popul Vuh and to listen to the voices of the heroines and saints of New France, "des amazones à la poursuite d'un fugitif céleste" (Marchessault 1975, 105), all caught in the web of the present tense of narration recirculating in the fragmentation and recombination of the narratives of these other continental and cosmic travellers. Defamiliarized and transformed in this way, they produce a different morphology for the textual and, by synecdoche, the urban corps. Returning from these wanderings through books and foreign places in the Eighth "Canto," the narrator steps out of the Greyhound bus at the Dorchester terminus with the eyes of the strangers she has encountered, eyes of the outsider, of those on the margin, where the author situates herself sexually, textually and geographically - "le territoire des femmes en général" (Potvin 222).

It is on the margins, literally, of Montréal, au "Bout-de-l'Ile" also known as "Bas de l'Tle," that Marchessault locates a possible territory for the feminine. This tip of the island is the space of childhood, the domain of Grandmother, where she gathers her herbs, practices her traditional knowledge as healer and midwife, at the tip of the island where the waters gather and flow onward. For though Montréal holds the promise of new modalities of exchange for signs and bodies, Montréal has suffered from the great malady of silence emanating from the "plus bel édifice de la ville de Montréal," as Marchessault with irony describes the Bishop's Palace at the corner of Saint-Denis and Sainte-Catherine, "pavoisé" at Confederation, this conjunction of spiritual and temporal authority figuring as her metaphor for patriarchal power. Under the direction of these institutions with their joined repressive forces, the city becomes static, stagnant, under the authoritarian rule of law that banishes all spontaneity, all celebration. This is the sinister death-like city of the nineteenth-century literary imagination. Like the European midnight and underground spaces, Mort-réal has its lugubrious streets and squalid neighbourhoods lined with houses infested with rats who gnaw on the electric wires and plunge the shivering occupants into 
obscurity (Marchessault 1975, 244). The vividness of Marchessault's metaphor demonstrates the way she takes up the conventional tropes of the urban imaginary and reworks them, turning an image of death and stasis into one of active animation through the will to live of the animals, trace of the earlier wilderness still working through the urban networks. This is the company kept by working class families, people who work in factories processing furs, textiles, bombs, or who act as delivery people circulating these goods through the city, like the family of the narrator who move from one "trou" to another - inching up the mountain from Workman, Coursol, Quesnel, Parthenais and Beaudry - "dérivons de déménagement en déménagement," climbing finally to the Plateau Mont-Royal, rue Boyer (Marchessault 1975, 241). Movement here is constrained within the circles of routine, going around and around on itself, no longer wandering freely over the continent. From this impasse where she can neither advance nor retreat, the narrator is extricated by Grandmother Louisa, métis and nomade, artist and herbalist, the mother goddess in her form as Plant mother or fertility goddess, a "grande baleine" who has beached herself at "Bout-de-l'Ile," the Pointe-auxTrembles, at the end of Soixantième Avenue in a house a few feet from. the river. Here city merges into country, the houses surrounded by fields of oats, cows, trees. In this site in-between, the narrator chooses to live when she is cast out by the stars, falling into a family she calls a "tribu" of nomades living in harmony on aboriginal territory (Marchessault 1975,347). This election of the chosen land, the birth of this child-goddess from the Celestial Bear and Louisa, is the beginning/end of the narrative towards which Le crachat solaire spirals. Repeating the inaugurating parturition of Montréal from Bear Mother, this gestus constitutes the narrator as culture hero inaugurating a new age, a new ordering of the city in the feminine, one marked by the confluence rather than disjunction of animal and human realms.

At this liminal point, between city and wilderness, at the end of the Rue Notre Dame bus route where land, sea, sky converge, the narrator of La mère des herbes comes to seek regeneration from her grandmother Louisa, a sort of angel or "telluric woman" who transmits "les paroles de femme" through which the narrator is lead toward "le grand courant océanique" (Marchessault 1980,34). The narrator takes up and perpetuates the nomadic life-style of her Grandmother, whose wanderings through the forest on traplines and across the continent with the circus 
are a revitalizing model, a mediator to the realm of plants and animals. "Regarder le fleuve ou regarder grand'mère, c'était presque la même chose" (Marchesssault 1980, 237). Grandmother is all flowing mat(t)er: "du grand fleuve de matière qui l'alimente" (Marchessault 1975, 256). Through her, the narrator is connected metonymically to desiring women and to the feminine principle. For, as Marchessault claims, "ces femmes telluriques se rejoignent toutes" (Potvin 222). Through them too, Marchessault's writing connects to her sculptures of telluric women crafted in a moment of contact with the dance of the life force, "un monde cosmique spirituel, psychique, cellulaire et moléculaire" (Potvin 219). Such ardent life is possible only on the elevated level of global panorama, as the aviators in Des cailloux blancs... signify.

Marchessault's writing retells the drama of loss and recovery of a universe of limitless plenitude in artistic creation and desire among women in contrast to the limitations of a terrestrial and patriarchalorder configured by the city, space of exploited bodies and blocked signs. It is a city to be moved through by generating an / other world. Grandmother leads the way, driving across Canada with her infant son, rejecting constraint as she shouts out "Défi à ceux qui ne pensent qu'à tisser, qu'à resserrer, qu'à couper, qu'à nouer!" (Marchessault 1975, 286-7). She refuses the submission to institutions demanded of Native peoples, following the way of her Native mother and husband John-marchaitterre, that of "les errances, les partances" (Marchessault 1975, 271), postponing narrative closure. Rejecting the city's immobilizing unidimensionality for dynamic interactions, Marchessault mobilizes the signifying system along the trajectory of desiring women to intervene in the production of meaning, to reconfigure the body politic. "J'amorce des dialogues, j'inaugure plus d'une métamorphose et je danse une danse créatrice avec des mots fraîchement débarqués en Amérique" (Marchessault 1980, 179). As a woman, she is speaking in the city, but against it, speaking the city other/wise. Woman in flight, she plays out this metonymy of the city beyond the city. In this, the ambiguity and paradox of the city-sign is performed, displacing its propensity for closure, stasis, opening different possibilities, configuring possible worlds, fictions to change the real. Such fictions will transform the relations of centre and margins, city and surroundings, both spatial and temporal. In this liminal site of potentiality may be imag(in)ed a dynamic territory of women. 


\section{Works Cited}

Brossard, Nicole. French Kiss (1974). Montréal: Quinze, 1980.

Gelfant, Blanche. The American City Novel. Norman: U Oklahoma P, 1954.

Godard, Barbara. "En mémoire de l'avenir: Les stratégies de transfor-

mation dans la narration de Jovette Marchessault." Voix et images. 49

(automne 1991): 100-115.

. "The Geography of Separatism." Revue de l'Université

Laurentienne. IX, 1 (novembre 1977): 46-62.

Hébert, Anne. Le premier jardin. Paris: Seuil, 1988.

Lefebvre, Henri. Le droit à la ville. Paris: Anthropos, 1968.

Marchessault, Jovette. Comme une enfant de la terre/1. Le crachat solaire. Montréal: Leméac, 1975.

. La mère des herbes. Montréal: Quinze, 1980.

- Des cailloux blancs pour les forêts obscures. Montréal: Leméac, 1988. . "Les vaches de nuit." Tryptique lesbien. Montréal: Éditions de la

Pleine Lune, 1980.

Michaud, Ginette. "De la 'Primitive Ville' à la Place Ville-Marie: lectures de quelques récits de fondation de Montréal." in Nepreu and Marcotte, Montréal imaginaire: Ville et littérature: 13-95.

Morin, Marie. Les Annales de l'Hôtel-Dieu de Montréal. 1659-1725. Histoire simple et véritable. Montréal: Presses de l'Université de Montréal, 1979.

Moyes, Lianne. "French Kiss in the Urban Corps." Paper presented at "Montréal and Vancouver: Imagining and Writing our Cities." Simon Fraser University, March 1993.

Nepveu, Pierre et Gilles Marcotte. Montréal imaginaire: Ville et littérature. Montréal: Fides, 1992.

Olier, Jacques. Les Véritables Motifs de Messieurs et Dames de la Société de Notre-Dame de Montréal pour la conversion des Sauvages de la Nouvelle France (1643). Mémoires de la Société historique de Montréal, neuvième livraison. Montréal: Berthiaume et Sabourin, 1880.

Pike, Burton.The Image of the City in Modern Literature. Princeton: Princeton U P, 1981.

Potvin, Claudine. "Entrevue avec Jovette Marchessault." Voix et images. 47 (hiver 1991): 218-229.

Roy, Gabrielle. La petite poule d'eau. Montréal: Beauchemin, 1950. 
Tâché, Joseph-Charles. Forestiers et voyageurs (1863). Montréal: Fides, 1946.

Thompson [Godard], Barbara J. "The City of Montreal in the English and French Canadian Novel, 1945-1965." M.A. Thesis, Université de Montréal, 1967.

\section{Notes}

1 This text was first written en français for Les Bâtisseuses de la Cité - 350 ans de vie de femmes à Montréal and was substantially revised for a conference on Montréal and Vancouver, Simon Fraser University, March 1993. Further revised here.

2 Utopian, I write as a question. Marchessault's writing in the future perfect is a type of utopian writing developed from the overlapping of different historical moments rather than the juxtaposition of two spatial worlds. It is a dynamic concept of utopia, one that plays on the heterotopia of liminal spaces, mixed or border zones. I have discussed this at greater length elsewhere (Godard 1991).

3 This vision of a métis culture in Québec might be seen in light of present debates over imperialism as an instance of "cultural appropriation" or "totem transfer" in which the white settler population nativizes itself as Canadian through a process of symbolic indigenization. In this case, however, it should be read as an instance of "strategic essentialism," Jovette Marchessault claiming her own Native heritage that has been invisible in her perceived Québec identity.

4 In this, Marchessault reworks the telluric myth central to Québec agriculturalist ideology, the culture hero born of a sky mother and earth grandmother in her version, not from the sky father and earth mother in the dominant version as in Louis Hémon's Maria Chapdelaine, for example.

5 In Mohawk mythology, for example, the mother of the people comes down to float on a turtle's back. The earth is consequently called by Natives "Turtle Island." The Clan Mother of the Turtle Clan is the preeminent political and spiritual personage of the tribe.

6 Anne Hébert reworks quotations from Mère Marie de l'Incarnation in Le premier jardin, a narrative of mysterious origins that re-members Québec city. Nicole Brossard quotes a passage from the work of Marie Morin, "des prairies émaillées de fleurs de toutes couleurs," in French Kiss (Brossard $1980,50)$. This text is also concerned with the relations between. book/body / city and desire between women, as Lianne Moyes notes. 